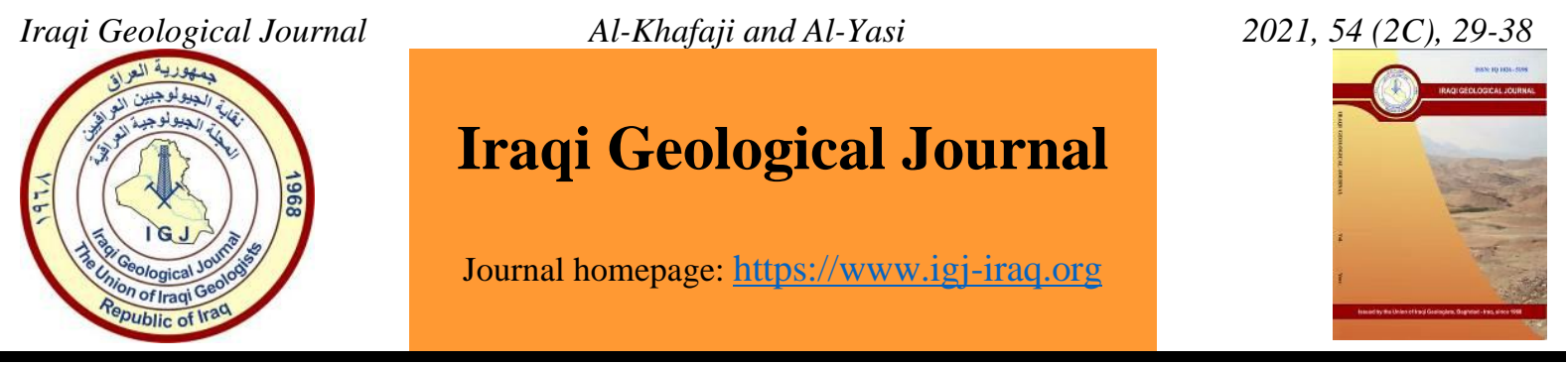

\title{
Analyzing Gravity and Magnetic Data for the Detection of Deep-Seated Faults and Faults within the Sedimentary Cover Near Habbanieyah and Razzaza Lakes in the Middle of Iraq
}

\author{
Wadhah Mahmood Shakir AL-Khafaji ${ }^{1, *}$ and Ameen Ibraheem Al-Yasi ${ }^{2}$ \\ 1 Department of Geophysics, College of Remote Sensing and Geophysics, ALKarkh University of Science \\ 2 Department of Geology, College of Science, University of Baghdad \\ * Correspondence: wadhahmk@yahoo.com
}

Received: 2 May 2021; Accepted:10 June 2021; Published: 30 September 2021

\begin{abstract}
This research deals with the processing and analyzing of magnetic and gravitational data for an area covering the region of Habbanieyah - Razzaza Lakes and its adjacent areas. The study includes data processing and mapping of the total gravity and magnetic anomalies for only the concerned region, then separating the residual anomalies by adopting the polynomial regression graphical method. The residual gravity anomaly reflects the variations of rock densities within the sedimentary cover. The horizontal gradient filter has been applied to the residual gravity anomaly in order to conduct the locations of fault planes within the sedimentary cover where sudden variations of gravity field take place. The quantitative interpretation for both gravity and magnetic anomalies yielded a preliminary determination for the depth to the center of major faults within the sedimentary cover. By constructing a gravity model along a profile which directed NE-SW and passing through the middle part of the study region, depth to the center of the effective faults found. This depth variation is due to the effect of tectonic activity which produced a set of faults, such faults caused the upward and downward structural motions and were responsible for positioning the deep high density causative slabs of bedrock. The residual magnetic field quantitative interpretation along two profiles crosses over anomalies at the NE and SW parts of the region yielded the depth to the top of magnetized basement rocks. The difference in depth of the basement rocks and the shifted anomaly locations reflects the effect of tectonic activity which may relate to a strike slip faulting in the higher depths.
\end{abstract}

Keywords: Gravity analysis; Magnetic analysis; Faults detection; Habbanieyah; Razzaza; Gravity fault model

\section{Introduction}

The gravity method was successful in detecting basement rocks structures in which some of them are affected by uplift structural motions, also, some of these structures could be promising locations for mining and petroleum exploration (Saibi et al., 2021). The two-dimensional models derived from gravity profiles are very effective in detecting subsurface graben faults or trenches which are produced by shifting of normal faults (Hasanah et al., 2016). The combination between gravity and magnetic data processing filtering and interpretation is very helpful in detecting subsurface structures, especially faults and their trending also to find the depth to the basement rocks (Eshanibli et al., 2021). Deducing the residual Bouguer anomaly map is applicable in detecting fault locations and their extension. DOI: $\underline{10.46717 / i g j .54 .2 C .3 M s-2021-09-22}$ 
Furthermore, gravity horizontal gradient maps could be used to detect high gradients anomalies over subsurface fault planes, this could also be helpful when deriving quantitative interpretations along a certain profile within the surveyed area. Furthermore, gravity modeling helped find the depth to the fault plane center which was found about $2.5 \mathrm{Km}$ toward the SW direction of Qa'im city in Iraq (Al-Khafaji, 2017). The current research aims to investigate the locations, depths and extensions of the major faults within the sedimentary cover, those which are extends to higher depths within the basement rocks, also, to provide a clear vision about faults and the subsurface structural situation of the region.

\section{Location and Geology}

The study area represents a region located in the Middle of Iraq and covers the location of Habbanieyah and Razzaza lakes. The region is bounded by the coordinates Lat. $32^{\circ} 30^{\prime}-33^{\circ} 30^{\prime} \mathrm{E}$ and Long. $42^{\circ} 00^{\prime} 43^{\circ} 00^{\prime} \mathrm{N}$. The area is of about $10000 \mathrm{Km}^{2}$ (Fig.1). The age of the exposed surface rocks at the study region is ranging between Early Miocene and Holocene. Generally, older rock outcrops at the western banks of the two lakes, which are: Fluvial sediments of Quarternary: It includes conglomerate sediments of Al-Fatha fan which belongs to Pleistocene; these sediments could be found mainly exposed at the northern bank of Habbanieyah Lake and shown in brown color in the Fig. 1. A gypsum layer which belongs to Holocene shows up along the eastern side of both Habbaniya and Razzaza Lakes (Yacoub, 2011).

Zahrah Formation: The rocks of this formation represent the Upper Miocene to Middle Miocene sedimentary cycle. It belongs particularly to the age of Middle Miocene. It is mainly consisting of white reddish limestone and some sandy-marly-calcareous sandy limestone. The outcrop of this formation rocks appears in the color of light yellow at the northern west part of the study region inside the map of Fig.1 Injana Formation: Its mainly consist of sandstone, claystone and siltstone. The rocks of this formation belong to Middle and Upper Miocene age. Injana Formation rocks are exposed at the northern and eastern parts of Razzaza Lake, which appears in pink color (Fig.1). The rocks of this formation show some patches of gypsum (Abdul-Jabbar, 2013). The rocks of Injana Formation Outcrops show up some patches of gypsum. These outcrops show up at the eastern side of Razzaza Lake. The Injana formation rocks extend in a shape of a narrow pinch along the eastern bank of Habbaniya Lake.

Fatha Formation: It represents the rocks of Middle Miocene and shows up mainly to the west of Razzaza Lake, it is shown in yellow inside the map of Fig.1. Fatha Formation rocks show evaporate facies, which are mainly thick beds of gypsum and anhydrite. Such rocks found in a cyclic manner with marly-claystone and limestone (Bellen et al., 1959). Fatha Formation rocks appear in the dark yellow color inside the map of ig. 1 and cover a large area to the north western bank of Razzaza Lake.

Al-Ghar and Al-Furat formations: These rocks belong to Lower Miocene and exposed at the western banks of Razzaza Lake. It appears in orange color inside the map of Fig.1. Al-Ghar Formation rocks belongs to lower Miocene and mainly consist of sand and gravel with few beds of anhydrite, also, clayey-sandy limestone this reflects the tidal or deltaic sedimentation environment. The ager rocks of Al-Furat Formation are exposed to surface at the western banks of Habbanieyah and Razzaza lakes they belong to the age of early Miocene. Al-Furat Formation rocks are mainly consisting of shelly, chalky, well bedded re-crystalline limestone (Bellen et al., 1959). The Upper Unit of Al-Furat Formation represents mostly the western bank of Habbaniya and Razzaza Lakes. It is mainly consisting of soft, fossiliferous blue- green marlstone, interbedded with thin beds of shelly re-crystalline limestone or shelly Oolitic limestone. (Sissakian and Mohammed, 2007). 


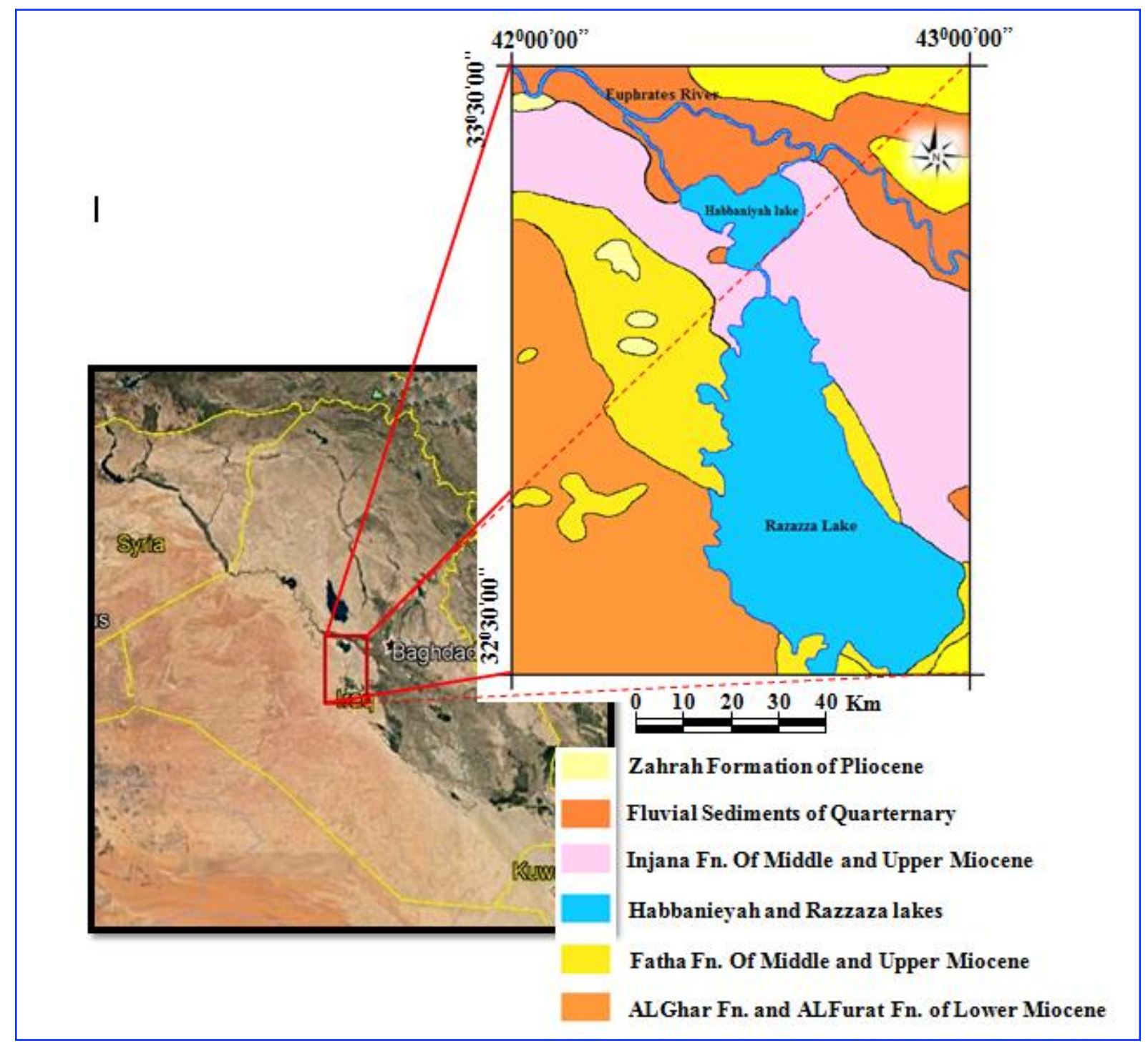

Fig.1. The location and surface geology of the study region

The magnetized basement rocks of Iraq are generally not exposed to the surface, also, there are no boreholes dug to penetrate the whole thickness of the sedimentary cover. Therefore, available information concerning the depth and properties of the basement rocks are predicted by several geophysical studies indirectly. The model of basement rocks depth was conducted with the support of geological information which depended on the thickness of mega sequences (Getech and Jassim, 2002 in Jassim and Goff, 2006). Fig.2 shows a central basement high (at depth of 5-7 km) flanked by two major structural lows on either side. This high is called Salman Zone (Jassim and Goff, 2006). The depth to the basement rocks in the study region (Fig. 2) is approximated to be 7-9 km according to the previous reference map. These depth values are little in comparison with the depths of the basement which presented by previous studies in the region. Jassim and Goff, 2006, have interpreted three major and older fault systems in Iraq and viewed their influence on the thickness of major stratigraphic intervals. They relied mainly on gravity data in faults identification. This data processing was integrated with magnetic and satellite imagery. The main fault systems are the northwest southeast trending (Najd Faulting System), the northeast-southwest trending (Transversal faulting system) and the north-south (Nabitah faulting system). 


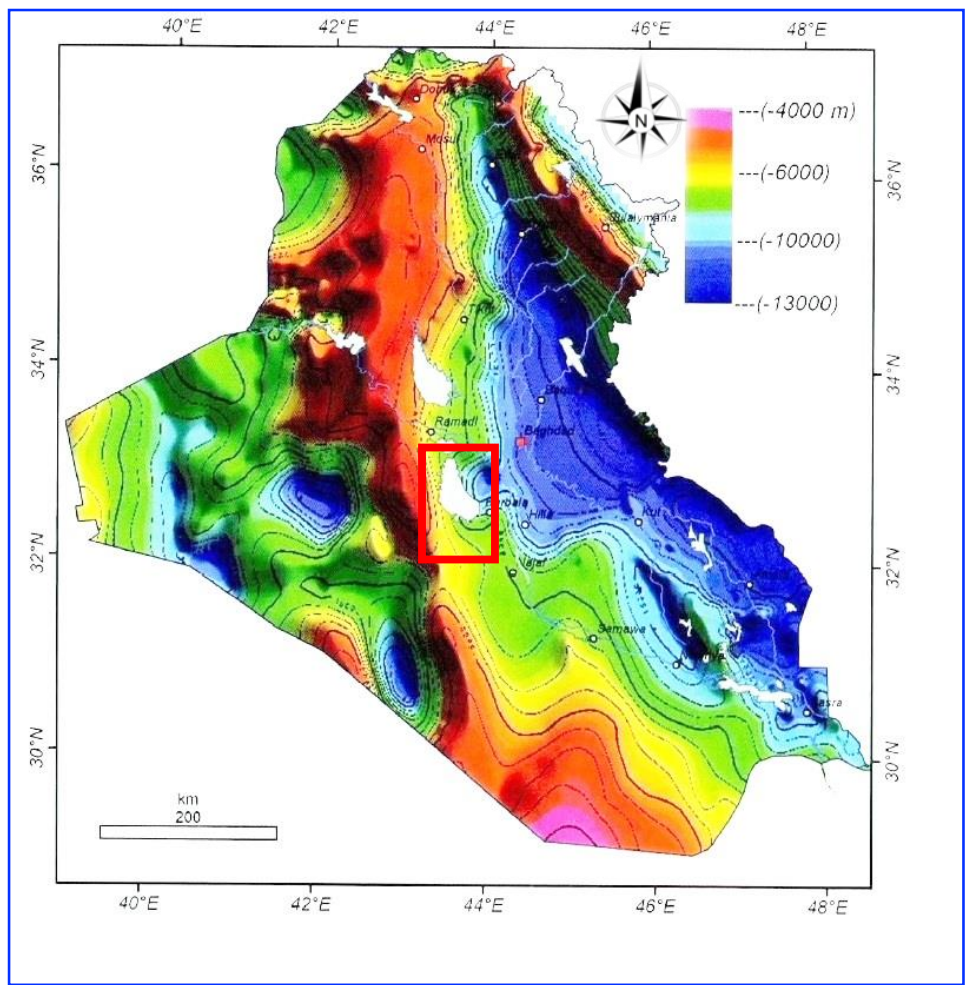

Fig.2. 3D inversion of Gravity data depth to basement rocks. Primarily the study region (red rectangle) shows basement rocks depth of about 6000 to 7000 meters, (Getech and Jassim, 2002) modified

By observing Fig. 3, one can tell that one of the greatest faults in the region is (Abu Jir) major fault which situated at the western flanks of Razzaza and Habbanieyah lakes. Furthermore, the

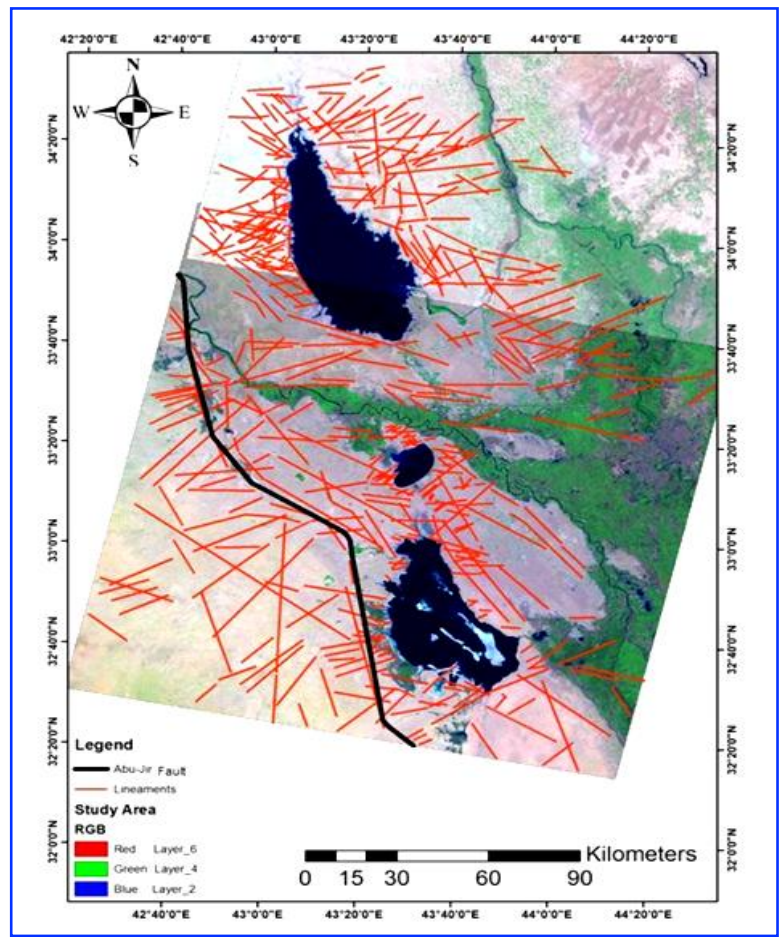

Fig. 3. Lineaments map of the study region shows the directions of linear structures such as faults, also the location of Abu Jir major fault toward the east of Habbanieyah and Razzaza Lakes (Abdul-Jabbar, 2013) 
lineaments give a preliminary idea about some fault's direction and locations within the study region. The Habaniya and Razzaza Depressions are located at the central part of Iraq, west to Tigris River. The exposed to surface rocks age ranged between Early Miocene to Holocene. It represents AlFurat Formation which belongs to Early Miocene, Fatha Formation of Middle Miocene, Injana Formation of Late Miocene, the Dibdibba Formation of Pliocene-Pleistocene, and the sediments of Quaternary. The lake depression forms the western margin of Mesopotamia Zone along Al-Salman Zone. The sedimentary basin suffered a strike slip movement during Miocene age, as referred by (AbdulJabbar, 2013). This structural movement caused an additional extension which continued during the Late Miocene until the Early Quaternary. The structural motion worked in reactivating some faults and made their effect reaching the near surface rocks; also, this movement produced the development of some geological features. Some of these features are Habbaniya and Razzaza depressions. The reactivated faults played an important role in developing depressions due to the relatively smaller thickness of rock sequences; this caused that hydrogen sulfate groundwater to rise from deep formations toward the shallow rocks through gypsum and limestone rocks. The latter process produced collapses in the depressed area in addition to the effect of the early extension process which produced groundwater horizontal movement (Abdul-Jabbar, 2013). Several subsurface structural features were observed in Habbaniya and Razzaza depressions. As a rule of thumb, most of near surface structures follows the subsurface structural features. Generally, the distinguished subsurface structural features are folds and faults with a possibility of petrol structural traps presence especially beneath Razzaza Lake (Al-Sakeni, 1984). It is also worth to mention that the two lakes which are located in the middle part of Iraq considered as an important source of relatively fresh water, especially, Habbanieyah water which found suitable for agricultural irrigation and for drinking consumption (Al-Kubaisi, 2020).

\section{Materials and Methods}

\subsection{Data Processing and Interpretation}

The original data of gravity was obtained from the total Bouguer gravity map of Iraq, in addition to the magnetic data which obtained from the CGG aero magnetic map of Iraq. The original maps where gridded manually for only the concerned part of the studied region in order to transform it into an electronic data map by increasing its contour density and to be able to apply digital filtering to enhance data display across the region. The processing of the gravity and magnetic data were performed by adopting the following steps:

- The manual gridding for the original gravity and magnetic maps. This has been done for the only concerned region in this study which represents the lakes of Habbanieyah and Razzaza and around areas. The grid was $5 \times 5 \mathrm{~km}$ according to the original maps scale which was 1:1000000.

- Grid nodes values read from the original maps after increasing contour density manually, then, node values arranged in a table to make it ready for computer input.

- An excel format files created for both total gravity and total magnetic fields. These files were ready to be imported to computer software to construct the digital maps of the total gravity and magnetic fields.

- A graphical method adopted to separate the residual field from the total field. This has been applied for both total gravity and magnetic fields of the region. This graphical method represents the calculation of the polynomial regression for the total gravity and total magnetic fields in order to obtain the regional fields (Sharma, 1988). Choosing the calculated $2^{\text {nd }}$ order polynomial regression in obtaining regional field depended on the trial of $1 \mathrm{st}, 2^{\text {nd }}$ and $3^{\text {rd }} \ldots$ etc. orders, but the $2^{\text {nd }}$ order 
chosen because it produced the most satisfactory representative surface for the regional field. The resulted data grid nodes of the regional field then subtracted from the total field grid nodes to obtain the residual fields.

- The residual gravity field map (Fig.4) considered as the cornerstone in the later interpretation procedures, also the same procedures were applied on the residual magnetic field which shown in Fig. 5.

\subsubsection{Residual bouguer anomaly interpretation}

The residual Bouguer anomaly map represents the gravity effect of the sedimentary cover over the basement rocks that the location of the tow lakes is particularly over the eastern negative anomalies of the region. It represents a natural depression formed by the tectonic and structural activity, (Fig.4). Faults have their effect in producing this depression as it going to be interpreted by deducing the gravity model along the profile A-A' (Fig. 5). Habbanieyah and Razzaza Lakes are located toward the east of a major fault which mentioned in many previous studies, this major fault called (Abu-Jir) fault. A depth model conducted and presented below the gravity profile in order to give a clearer vision about the structural situation and the effect of faulting in forming these depressions, (Fig. 5).

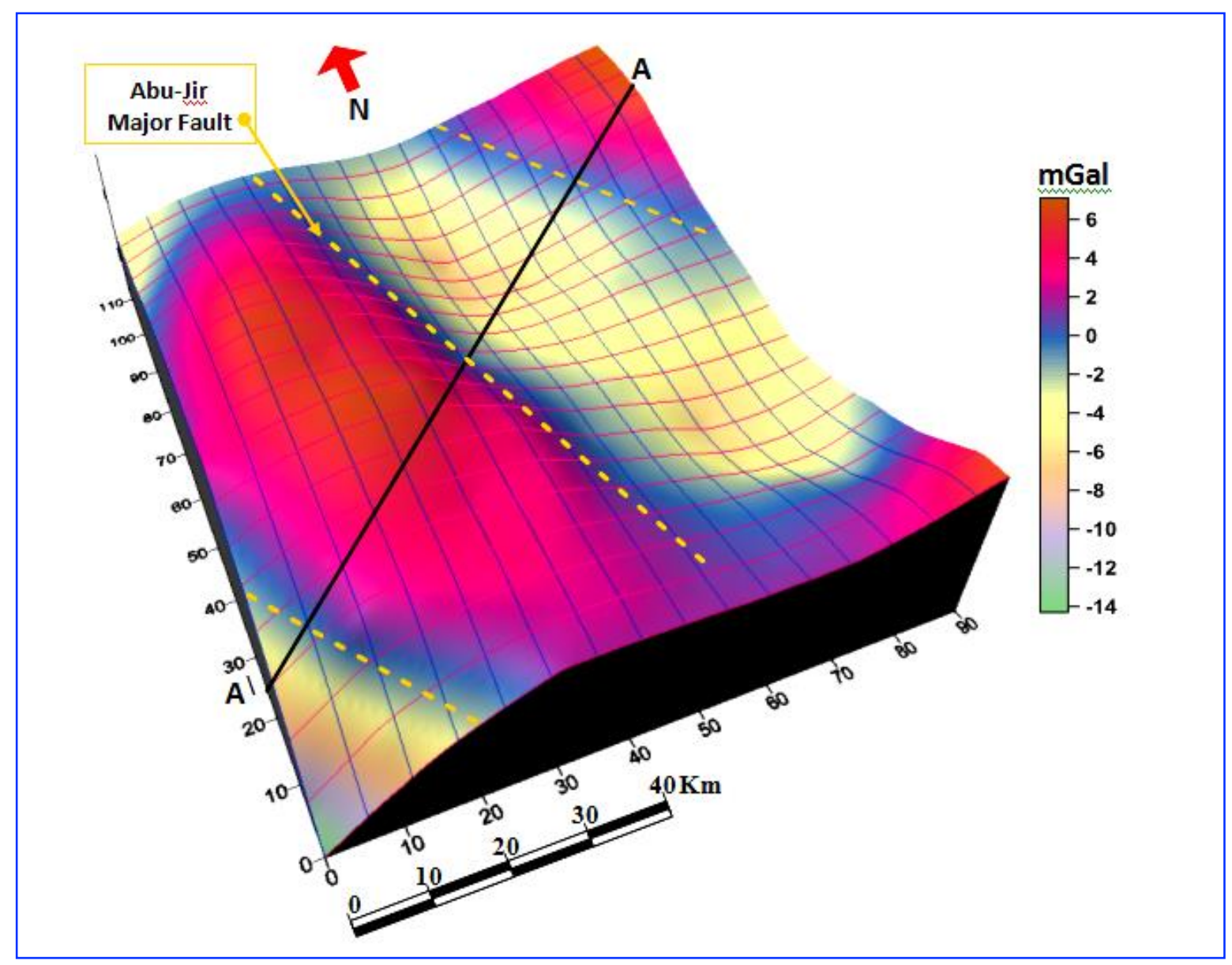

Fig.4. Showing the residual gravity field of the study region as a $3 \mathrm{D}$ visualized surface, also the locations of the detected major faults and the profile line A-A! 


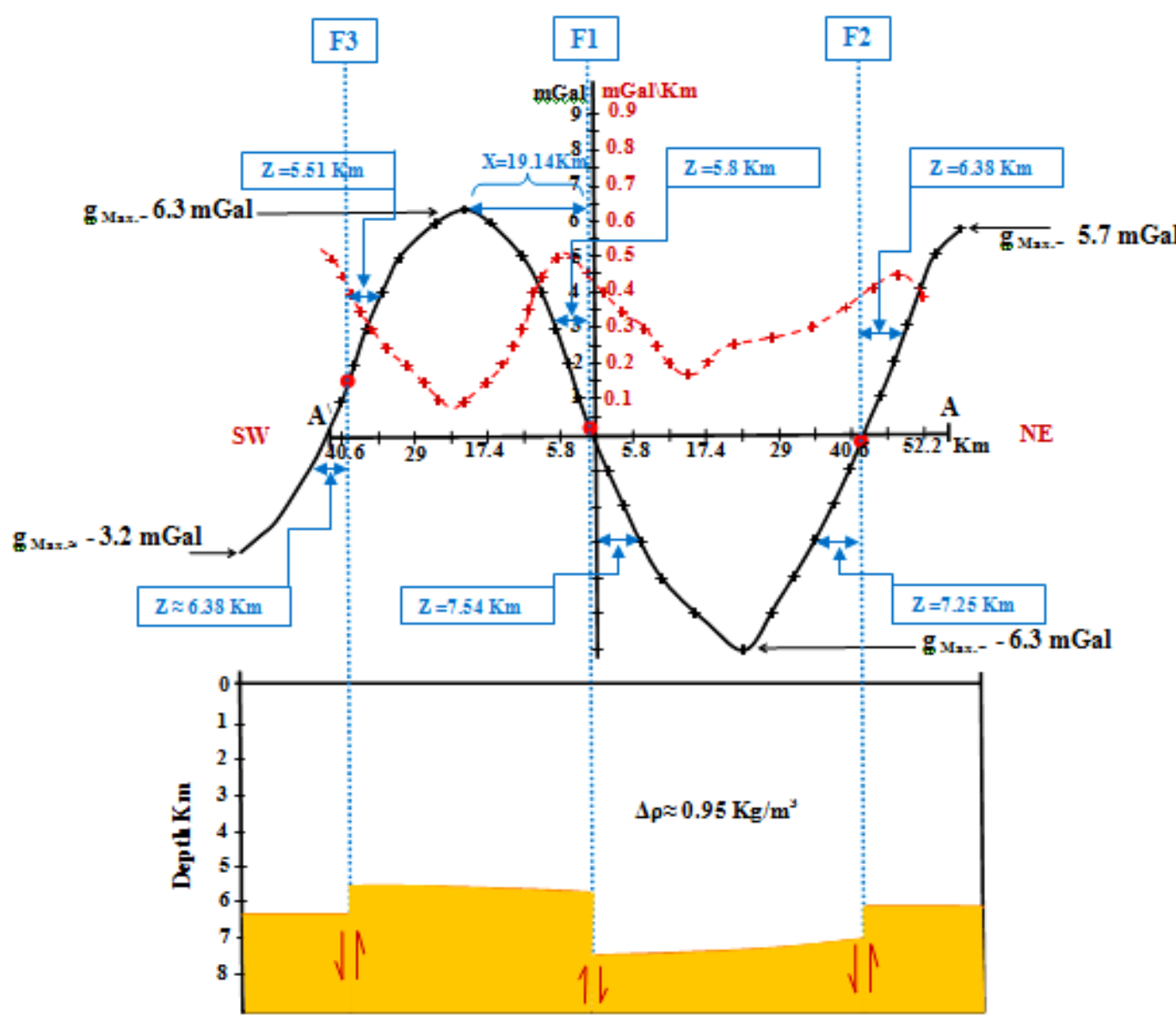

Key:

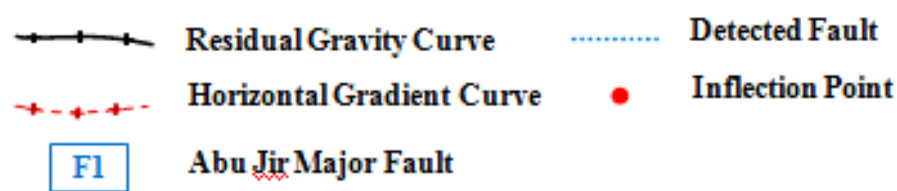

Fig.5. Residual bouguer and the absolute horizontal gradient variations along the profile line $\mathrm{A}-\mathrm{A}^{\prime}$ in the study region, a depth model is conducted by calculating depths to the center of the effective faults.

Usually, inflection points in the residual gravity profile (red points in Fig.5), refers to the locations of fault planes as it mentioned by Toushmalani (2010). Positive parts of the anomaly are mainly produced by a higher density causative slabs which has a density $(t)$ and surrounded by hosting rocks with less density. The density contrast between the causative slab and the hosting rocks is expressed by $\Delta \rho$. The depth to the center of the effective slab (z) represents the horizontal distance when the anomaly mode varies from $0.5 \Delta$ gmax to $0.25 \Delta$ gmax or $0.75 \Delta$ gmax, (AL-Khafaji and AL-Dabbagh, 2019). The gravity difference around a fault could be expressed by the following equation (1), (Dobrin, 1976; Sharma, 1986):

$$
\Delta \mathrm{g}=2 \mathrm{G} \mathrm{t} \Delta \rho\left(\pi \frac{-}{2}-\tan ^{-1} \mathrm{x} \backslash \mathrm{z}\right) .
$$

Where: $\mathrm{G}$ is the gravity constant, $\Delta \rho$ is the density contrast between the causative slab and the hosting rocks, $\mathrm{t}=$ thickness of the causative slab, $\mathrm{x}=$ the distance from the anomaly minima observation 
point to the horizontal location of the inflection point, $\mathrm{z}=$ depth to the center of the causative slab. The horizontal gravity gradient also plotted along the same profile line, Fig.5, which shown as red disconnected line. The horizontal gradient shows positive peaks over inflection points to assure the locations of faulting planes. The depth (z) was calculated around both sides of the three inflection points along the profile A-A', and then a depth model conducted and drew below the gravity profile by using the same distance scale. The depth $(\mathrm{z})$ was variable between $5.5-7.5 \mathrm{Km}$.

\subsubsection{Residual magnetic anomaly interpretation}

Two magnetic profiles were chosen to be interpreted within the region (Fig.6), the first profile line is $B-B^{\backslash}$ which located at the NE part of the region, and the other profile is $C_{-} C^{`}$ which located at SW part of the region. The aim was to find the depth to the surface of the magnetized basement rocks which are responsible of producing the magnetic anomaly. Dipolar magnetic anomalies along the profiles $\mathrm{B}-\mathrm{B}^{\backslash}$ and C-C $\mathrm{C}^{\prime}$ are interpreted quantitatively by adopting Peters method in order to find the depth to the top of the causative magnetized basement rocks (Fig.7). The interpretation procedures are explained briefly by (Milsom, 2003). Quantitative interpretation results showed that this depth is about $6.56 \mathrm{Km}$ at the NE part of the region and about $6.25 \mathrm{Km}$ at the SW part of the region.

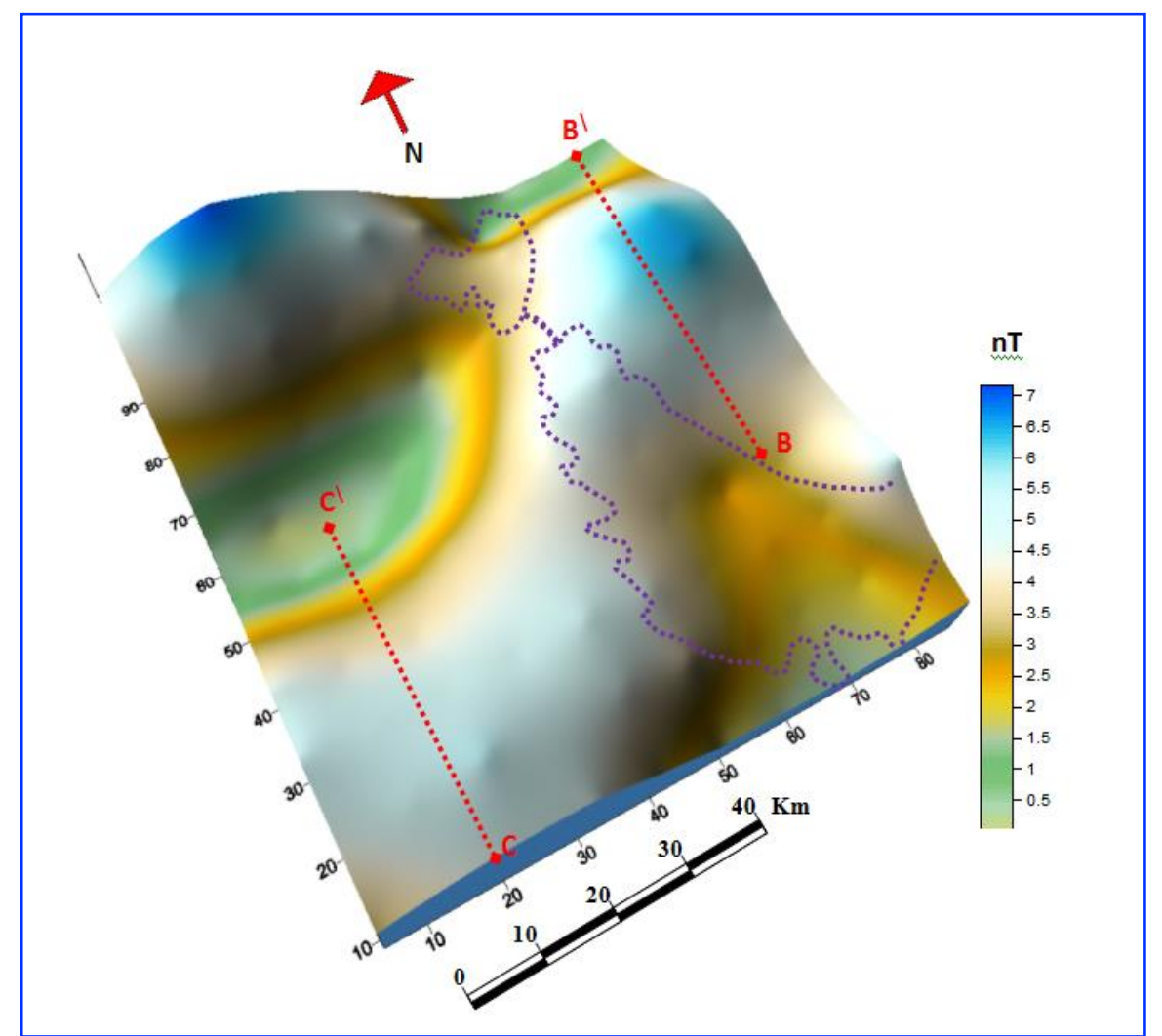

Fig. 6. A 3D visualization surface showing the dipolar residual magnetic field of Habbanieyah Razzaza region and the magnetic profile lines $\mathrm{A}-\mathrm{A}^{\prime}$ and $\mathrm{B}-\mathrm{B}$

\section{Results and Discussion}

Gravity depth model along the profile A-A ', (Fig.5), was conducted according to the effective slab method in calculating faults effective depth as discussed previously. The depth to the causative slab model revealed the locations and effective depth to three major faults in the region including the major Abu-Jir fault. Horizontal gradient of the residual gravity field, .5, was useful in detecting the locations of the three fault planes, furthermore, inflection points of the residual gravity anomaly was very helpful 
in detecting fault plane locations and considered as the start key in the quantitative interpretation as well. On the other hand, quantitative interpretation of magnetic anomalies for the profiles B-B ${ }^{\prime}$ and $C-C^{\prime}$, (Fig.7), was also helpful in finding depth to the top of the magnetized basement rocks at the NE and SW parts of the study region. Anomalies location shifting may related to the effect of strike slip faulting motion in higher depths as well. Depth results conducted from analyzing both gravity and magnetic data was very compatible with the results of previous geological studies.

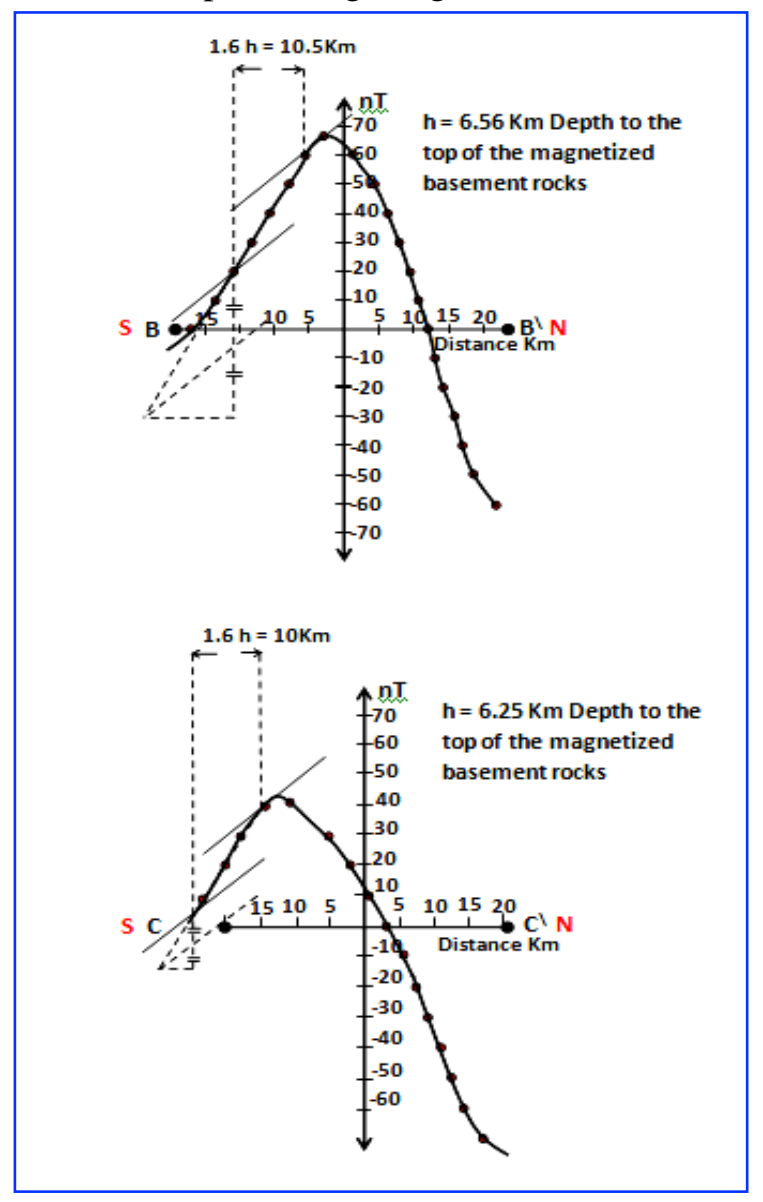

Fig.7. Peters method application in interpreting the magnetic profiles along the traverses B-B ${ }^{\backslash}$ which located toward the NE direction to the two lakes' and $\mathrm{C}-\mathrm{C}^{\prime}$ which located toward the SW direction to the two lakes, interpretation results represents the depth to the top of the magnetized basement rocks.

\section{Conclusions}

Gravity model along the profile A-A ${ }^{\prime}$ which directed NE-SW and passing through the middle part of the study region conducted in order to find the depth to the center of the effective faults or the causative slabs which found variable between 5.5 to $7.5 \mathrm{Km}$. This depth variation is may result due to the effect of tectonic activity which produced a set of faults, such faults caused the upward and downward structural motions which are similar to graben and horst fault motions and were responsible of positioning the deep high density causative slabs of bedrock. The residual magnetic field quantitative interpretation along two profiles at the NE and SW parts of the region yielded that depths to the top of magnetized bodies or the magnetized basement rocks were about $6.56 \mathrm{Km}$ at the NE part, and $6.25 \mathrm{Km}$ at the SW part of the region. This represents the depth to the basement rocks which produced the dipolar magnetic anomaly. The difference in depth of the basement rocks and the shifted anomaly locations reflects the effect of tectonic activity which may relate to the effect of strike slip faulting in the high depths of the basement rocks. 


\section{Acknowledgements}

The authors are very grateful to the Editor in Chief Prof. Dr. Salih M. Awadh, the Secretary of Journal Mr. Samir R. Hijab. and the Technical Editors for their great efforts and valuable comments.

\section{References}

Abdul-Jabbar A. A., 2013. Tectonic Study of Al-Thirthar, Al-Habbaniya, and Al-Razzazah Depressions, West of Tigris River, Iraq, Ph.D. Thesis, Department of Geology, College of Science, University of Baghdad, 118 pp.

Al-Khafaji W.M.S., 2017, Gravity field interpretation for major fault depth detection in a region located SWQa'im , Iraq, Baghdad Science Journal, 14 (3), 625-636.

AL-Khafaji, W.M. S. and Al-Dabbagh, H. A., 2019. A geophysical correlation between near-surface radioactivity and subsurface faults detected by gravity method for a region located In the western desert of Iraq, Iranian Journal of Earth Sciences, 11 (2), 95-103.

Al-Kubaisi, M. H. D., 2020. Hydrochemical facies description to assess the water quality of Habbaniya Lake Iraq, Iraqi Geological Journal, 53 (2F), 94-10.

Al-Sakeni, J., 1984. Origination of Al-Habbaniya and Al-Razzaza depressions and possibility of oil existence in structures which component them. Internal report of State Company of Oil and Gas Investigation.

Bellen, R. C. V., Dunnington, H. V. W. and Morton D. M., 1959. Lexique Stratigraphic International Asia. Fascicula 10a. Iraq. 333 pp.

Dobrin, M. B., 1976. Introduction to Geophysical Prospecting, McGraw Hill Inc., 747 pp.

Eshanibli, A. S., Osagie, A. U., Ismail, N.A., Ghanush, H. B., 2021. Analysis of gravity and aeromagnetic data to determine structural trend and basement depth beneath the Ajdabiya Trough in northeastern Libya, SN Applied Sciences, 3, 228.

Fouad, S. F. A., 2010, Tectonic and structural evolution of the Mesopotamia Foredeep, Iraq. Iraqi Bulletin of Geology and Mining, 6 (2), 41-53.

Getech and Jassim, S. Z., 2002, The Basin Development of Arabia, GETECH, School of Earth Sciences, University of Leeds. England, Repot No. G0227, 414 pp.

Hasanah L., Aminudin A., Ardi, N. D., Utomo A. S., Yuwono H., Kamtono, Wardhana, D. D., G aol K.L. and Iryanti M., 2016, Graben Structure Identification Using Gravity Method, IOP Publishing, IOP Conf. Series: Earth and Environmental Science, 29(1), 012013

Jassim, S.Z. and Goff, J.C., 2006. Geology of Iraq. Published by Dolin, Hlavni 2732, Prague and Moravian Museum, Zelnytrh 6, Brno, Czech Republic, $1^{\text {st }}$ ed. 341pages.

Milsom, J., 2003, Field geophysics, the geological field guide series, $3^{\text {rd }}$ Ed., Jhon Wiley \&Sons Ltd., England, $232 \mathrm{pp}$.

Saibi, H., Hag, D. B., Alamri, M. S. M., and Abdo, A. H., 2021. Subsurface structure investigation of the United Arab Emirates using gravity data, De Gruyter, Open Geosciences, 13, 262-271

Sharma, P. V., 1986. Geophysical Methods in Geology, 2nd Ed., Elsevier Science Publishing Company Incorporation, $442 \mathrm{pp}$.

Sissakian, V. K., and Mohammed, B. S., 2007. Geology of the Iraqi Western desert stratigraphy, Iraqi Bulletin of Geology and Mining, 1, 51-124.

Toushmalani, R., 2010. Application of gravity method in fault path detection, Australian, Journal of Basic and Applied Sciences, 4:6450-6460.

Yacoub, S. Y., 2011. Stratigraphy of the Mesopotamia Plain, Iraqi Bulletin Geology Mining, 4, 47-82. 